\title{
Role of NO/cGMP signalling in VEGF-mediated angiogenesis
}

\author{
Ronald Jäger ${ }^{*}$, Dieter Groneberg, Andreas Friebe \\ From 5th International Conference on CGMP: Generators, Effectors and Therapeutic Implications \\ Halle, Germany. 24-26 June 2011
}

\section{Background}

NO-sensitive guanylyl cyclase (NO-GC) is the most important effector protein for nitric oxide $(\mathrm{NO})$ and is involved in various physiological processes. Binding of NO stimulates NO-GC up to 200 -fold and thereby increases cGMP synthesis. NO is generated by different NO synthases (NOS). In the vasculature, endothelial NOS (eNOS) is involved in the regulation of blood pressure by relaxation of vascular smooth muscle. eNOS is known to be stimulated by shear stress. In addition, NO synthesis is stimulated by vascular endothelial growth factor (VEGF) which acts as one of the most potent stimulators of angiogenesis.

Until now the exact signalling pathway of VEGFinduced NO has not been elucidated. S-nitrosylation of protein thiols as well as stimulation of NO-GC with subsequent cGMP increases may underlie the angiogenic effect of VEGF.

\section{Method}

In order to investigate the involvement of the NO/cGMP cascade in VEGF-mediated angiogenesis we generated an endothelial-specific NO-GC knock-out mouse (ECGCKO) using the Tie2-Cre line.

\section{Results}

Preliminary macroscopic analysis revealed that ECGCKO mice are indistinguishable from WT animals and do not show any of the gross phenotypes of the total GCKO mice. Several in vitro and in vivo techniques are being used such as primary endothelial cell culture, aortic ring assay and matrigel plug analysis.

* Correspondence: ronald.jaeger@uni-wuerzburg.de

Physiologisches Institut, Universität Würzburg
Published: 1 August 2011

doi:10.1186/1471-2210-11-S1-P35

Cite this article as: Jäger et al:: Role of NO/cGMP signalling in VEGFmediated angiogenesis. BMC Pharmacology 2011 11(Suppl 1):P35.
Submit your next manuscript to BioMed Central and take full advantage of:

- Convenient online submission

- Thorough peer review

- No space constraints or color figure charges

- Immediate publication on acceptance

- Inclusion in PubMed, CAS, Scopus and Google Scholar

- Research which is freely available for redistribution

\section{Biomed Central}

\section{Biomed Central}

